REGARDS

SUR L'ECONOMIE ALLEMAND

BULLETIN ECONOMIQUE DU CIRAC
Regards sur l'économie allemande

Bulletin économique du CIRAC

$67 \mid 2004$

Varia

\title{
Horaires des magasins : les Länder auront le choix
}

Isabelle Bourgeois

\section{CpenEdition}

\section{Journals}

Édition électronique

URL : http://journals.openedition.org/rea/3815

DOI : 10.4000/rea.3815

ISBN : 978-2-8218-0830-0

ISSN : 1965-0787

Éditeur

CIRAC

Édition imprimée

Date de publication : 1 juillet 2004

Pagination : 36

ISSN : 1156-8992

Référence électronique

Isabelle Bourgeois, "Horaires des magasins : les Länder auront le choix», Regards sur l'économie allemande [En ligne], 67 | juillet 2004, mis en ligne le 08 octobre 2009, consulté le 15 septembre 2020. URL : http://journals.openedition.org/rea/3815

Ce document a été généré automatiquement le 15 septembre 2020.

(C) CIRAC 


\title{
Horaires des magasins : les Länder auront le choix
}

\author{
Isabelle Bourgeois
}

1 Un arrêt de Karlsruhe en date du 9 juin sonne le glas de la loi Ladenschlussgesetz de 1956 qui, depuis son toilettage en 2003, autorise l'ouverture des magasins jusqu'à 20 heures, du lundi au samedi inclus (voir REA 60/03). A une très courte majorité, les juges ont déclaré la loi conforme à la Constitution, restant divisés sur la justification d'une réglementation qui ne préserve plus réellement les droits des salariés, tant elle souffre d'exceptions. Mais la Cour estime qu'il appartient aux Länder de la réformer. La question, qui implique un transfert de compétences, devrait être débattue au sein de la Commission sur la réforme du fédéralisme instituée voici quelques mois. Les Länder ont annoncé vouloir déréglementer l'ouverture des commerces. L'accueil réservé à l'arrêt est dans l'ensemble positif, la cour ayant préservé le dimanche chômé (voir REA 54/01). Mais l'impact sur la consommation d'une libéralisation des horaires les jours ouvrables seulement devrait rester marginal. (IB)

\section{INDEX}

Mots-clés : magasin, commerce, horaire, consommation, Länder, fédéralisme, distribution 